\title{
CARBON CREDIT ESTIMATION FROM COMPOSTING OF MUNICIPAL SOLID WASTE IN INDIA
}

\author{
Sunil Kumar \\ NEERI, India
}

\begin{abstract}
Management of municipal solid waste (MSW) is a complex problem for being faced all over the world. Rapid urbanization and industrialization have led to scarcity of land and other resources in urban areas and have increased the problem of disposal of the waste generated. The total MSW generation will continuously rise due to the outgoing urban growth. Uncontrolled haphazard dumping of MSW on the outskirts of towns and cities has created overflowing landfills, which are not only impossible to reclaim, but also have induced serious environmental implications through contributions to ground water pollution and global warming. Successful composting of MSW is also practiced in a few pockets in some cities of India but due to low compost quality, the market is very low. Moreover, the Government of India is determined to promote only composting technology for treatment of MSW as per the recommendation of Hon'ble Supreme Court of India based on the views from Expert Committee.
\end{abstract}

MSW generally has a considerable fraction of biodegradable materials, even though the proportions vary from region to region. Biotreatment has, for many decades, been the preferred method for effectively treating the biodegradable waste. Composting is an ancient, environmental friendly and globally recognized method of biotreatment and bioprocessing of MSW. Composting generates a recycled organic product and minimizes the waste quantity left for disposal, thereby reducing the demand for landfill sites. Different fractions of the biodegradable organic components eventually mineralize to $\mathrm{CO}_{2}$ and $\mathrm{H}_{2} \mathrm{O}$ at different rates.

The present paper describes the theoretical and experimental estimation of $\mathrm{CO}_{2}$ emission from composting of MSW in India, which gives tentative estimation of carbon credit from composting of MSW.

\section{KEYWORDS}

Biodegradable; Biotreatment; Composting; CDM; Emission.

\section{INTRODUCTION}

Special attention for management of MSW is the adoption of appropriate MSW management technology acceptable to the public. Contrary to the motto "development for good quality of life", rapid urbanization and industrialization have led to scarcity of open land and other resources in urban areas and have increased the problem of disposal of the waste generated. 
The daily per capita solid waste generation in India ranges from about $0.2 \mathrm{~kg}$ in small towns to $1.6 \mathrm{~kg}$ in large towns [1].

MSW generally has a considerable fraction of biodegradable materials, even though the proportions vary from region to region. Biotreatment has, for many decades, been the preferred method for effectively treating the biodegradable waste. The fundamental problem for effective and economically sound biotreatment involves the attainment of high process rates with increased intensities. The most desirable, and at the top of the hierarchy of the integrated MSW management system, is source reduction, which can be achieved through reuse and recycling. Composting generates a recycled organic product and minimizes the waste quantity left for disposal, thereby reducing the demand for landfill sites.

As stated earlier, composting is essentially a mass of interdependent bioprocesses carried out by an array of micro- and macro-organisms resulting in the decomposition of organic matter. Soil microbes oxidize organic compounds, and release essential minerals such as nitrogen, phosphorus, and sulfur, which plants need. This oxidation process is also called respiration, wherein carbon dioxide, water, and energy are produced followed by the release of minerals that are essential for the growth of plant and other soil organisms. Carbon dioxide escapes to the atmosphere. Different fractions of the biodegradable organic components during aerobic composting of MSW eventually mineralize to $\mathrm{CO}_{2}$ and $\mathrm{H}_{2} \mathrm{O}$ at different rates and hence an attempt has been made to estimate the $\mathrm{CO}_{2}$ emission from composting of MSW in India.

\section{OBJECTIVES AND SCOPE OF THE STUDY}

\subsection{Objectives}

- To develop the windrow composting process through experimental studies using MSW only involving minimum pre-preparation and pre-processing;

- Theoretical and experimental estimation of $\mathrm{CO}_{2}$ emission from composting process;

- To study the yield of $\mathrm{CO}_{2}$ emission which can be sequestered which otherwise will be escaped to the atmosphere increasing the global warming.

\subsection{Scope}

- In keeping with the depletion of conventional energy sources, resource recovery from $\mathrm{MSW}$ in the form of biogas supplements energy requirement;

- Reducing the load of MSW for disposal and subsequently the problems related with environmental quality degradation and public health deterioration;

- Developing process parameters required for composting technologies of MSW. Similarly, process and techno-economic viability will be worked out for the commercial application.

\section{MATERIALS AND METHODS}

MSW collected from Nagpur Municipal Corporation area was placed at the incineration site in NEERI. Windrows were made using the MSW for experiments by sorting of plastics, stones, synthetic clothes, metals, leathers, glass, etc. 
The field set up consisted of two windrows heaped $1.2 \mathrm{~m}$ high and $1.7 \mathrm{~m}$ wide. One amongst them was controlled and the other one was allowed to compost naturally. Under controlled conditions, the composting process proceeded rapidly than that composting naturally. Windrow composting of source separated MSW was monitored for parameters like temperature, moisture and organic matter content while compost stability was assessed via respirometric techniques. The temperature of the pile was monitored $3-4$ times per week at 28 points along the cross section of the pile to monitor the temperature profile changes during processing. The pile was turned at weekly intervals resulting in high core temperatures up to $74^{\circ} \mathrm{C}$. Temperature profiles were typical for windrow composting.

In laboratory set up as shown in Figure $l$ consists of $1 \mathrm{~kg}$ of MSW in a container artificially aerated from the bottom using an aerator. The container was provided with lid with two openings. One opening was for sprinkling water which was done once a week while the other opening was for $\mathrm{CO}_{2}$ emission estimation. Two different runs were carried out in laboratory experiments and $3 \mathrm{~kg}$ of waste sample was used in each run. The shredded sample was used and shredded to size $<10 \mathrm{~mm}$. This set up resembled the windrow composting in field. It was daily aerated for 3-6 hours and the gas was collected in impingers.

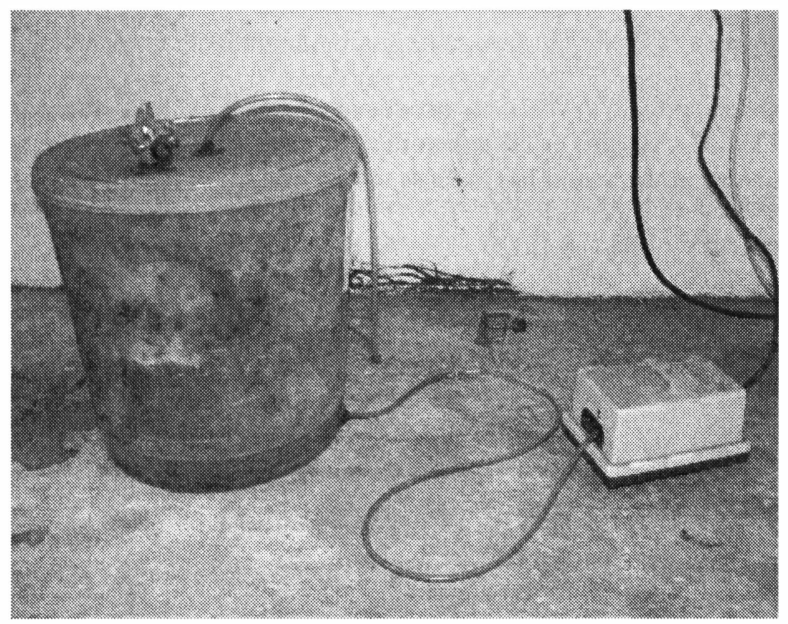

Figure 1. Laboratory set-up for composting of $\mathrm{MSW}$ and emission of $\mathrm{CO}_{2}$

\subsection{Theoretical procedure for $\mathrm{CO}_{2}$ emission estimation}

The $\mathrm{CO}_{2}$ emission estimation [2] is as follows:

$$
\mathrm{CE}_{a}=\mathrm{LOI}_{i}-\left(\mathrm{A}_{i} / \mathrm{A}_{\boldsymbol{o}}\right) \times \mathrm{LOI}_{o}
$$

This can be converted into $\mathrm{CO}_{2}$ emission as a percentage of biodegradable waste by the following equation: 


$$
\mathrm{CE}_{\boldsymbol{a}}=(44 / 12) \times\left[\mathrm{LOI}_{i}-\left(\mathrm{A}_{i} / \mathrm{A}_{\boldsymbol{o}}\right) \times \mathrm{LOI}_{\boldsymbol{o}}\right]
$$

Where $\mathrm{CE}_{\boldsymbol{a}}$ is the amount of $\mathrm{CO}_{2}$ emission from composting process as the percentage of biodegradable waste.

Hence, $\mathrm{CE}_{\boldsymbol{a}}=(44 / 12) \times\left[\mathrm{LOI}_{i}-\left(\mathrm{A}_{i} / \mathrm{A}_{\boldsymbol{o}}\right) \times \mathrm{LOI}_{\boldsymbol{o}}\right] \times 1000 / 100$

Where, $\mathrm{CE}_{\boldsymbol{a}}$ is the $\mathrm{kg}$ of $\mathrm{CO}_{2}$ emission/ton biodegradable waste.

In the anaerobic process in landfill, 2 moles of biodegradable $\mathrm{C} \rightarrow \mathrm{p}$ moles of $\mathrm{CH}_{4}+2 \mathrm{p}$ moles of $\mathrm{CO}_{2}$. Hence, $24 \mathrm{~kg}$ of biodegradable $\mathrm{C} \rightarrow 16 \mathrm{p} \mathrm{kg}$ of $\mathrm{CH}_{4}+44$ (2p) $\mathrm{kg}$ of $\mathrm{CO}_{2}$

Hence, $24 \mathrm{~kg}$ of biodegradable $\mathrm{C} \rightarrow\left(16 \mathrm{p} / \mathrm{dCH}_{4}\right) \mathrm{m}^{3}$ of $\mathrm{CH}_{4}+\left(44 \times 2 \mathrm{p} / \mathrm{dCO}_{2}\right) \mathrm{m}^{3}$ of $\mathrm{CO}_{2}$

$$
\begin{aligned}
& \mathrm{dCH}_{4}=1.87 \mathrm{~kg} / \mathrm{m}^{3} \\
& \mathrm{dCO}_{2}=0.688 \mathrm{~kg} / \mathrm{m}^{3}
\end{aligned}
$$

Hence, if there is 50:50 mixture of methane and carbon dioxide, then $\mathrm{p}=1$. Therefore, in an anaerobic landfill process, $24 \mathrm{~kg}$ of biodegradable $\mathrm{C} \rightarrow 16 \mathrm{~kg}_{\text {of } \mathrm{CH}_{4}}+44 \mathrm{~kg}$ of $\mathrm{CO}_{2}$

Therefore, in aerobic composting process, $24 \mathrm{~kg}$ of biodegradable $\mathrm{C} \rightarrow 88 \mathrm{~kg}$ of $\mathrm{CO}_{2}$

It follows, therefore, that $88 \mathrm{~kg}$ of $\mathrm{CO}_{2}$ produced aerobically in a composting process is equivalent to $16 \mathrm{~kg}$ of $\mathrm{CH}_{4}$ produced anaerobically in a landfill from the same amount of biodegradable $\mathrm{C}$, since in the anaerobic process, $44 \mathrm{~kg}$ of $\mathrm{CO}_{2}$ is also produced.

Therefore, MD project $=(44 / 12) \times[$ LOIi $-(\mathrm{Ai} / \mathrm{Ao}) \times \mathrm{LOIo}] \times(16 / 88)$

Where, MD project is measured as $\mathrm{kg}$ of $\mathrm{CH}_{4}$ / ton of biodegradable waste.

Converting this equation to tonnes of $\mathrm{CO}_{2}$ equivalent emission reduction gives:

ER project $=\left(\mathrm{GWP}_{\mathrm{CI} 4} / 1000\right) \times(44 / 12) \times[\mathrm{LOIi}-(\mathrm{Ai} / \mathrm{Ao}) \mathrm{LOIo}] \times(16 / 88)$

ERproject, y $=0.14 \mathrm{Wy}[\mathrm{LOIi}-(\mathrm{Ai} / \mathrm{Ao})$ LOlo $]$

Where, Wy is the total quantity of biodegradable waste processed by the composting activity in the year ' $y$ '.

The greenhouse gas emission reduction achieved by the project during year ' $y$ ' (ERy) is the difference between ER project, $y$, and the amount of methane that would have been destroyed /combusted during the year in the absence of the project activity (MDreg, y) times the approved Global Warming Potential for methane GWP $\mathrm{CH}_{14}$

$$
E R y=E R \text { project }, M_{\text {reg }} \text { y x GWP }
$$

\section{RESULTS AND DISCUSSION}

The physical composition of MSW after sorting for a $3 \mathrm{~kg}$ of sample is presented in Table 1 . 
Table 1. Physical Composition of MSW.

\begin{tabular}{cc}
\hline Different fractions of MSW & $\%$ Weight \\
\hline Leaves & 30.67 \\
\hline Coconut & 4.67 \\
\hline Paper & 11.49 \\
\hline Stone & 9.02 \\
\hline Cloth & 6.13 \\
\hline Vegetable & 5.88 \\
\hline Plastic & 11.75 \\
\hline Food & 3.20 \\
\hline Glass & 0.15 \\
\hline Grass / straw & 1.08 \\
\hline Fruits & 1.86 \\
\hline Rags & 0.88 \\
\hline Wood & 0.15 \\
\hline Rubber & 0.10 \\
\hline Coal & 0.10 \\
\hline Bone & 0.10 \\
\hline Ash \& Fine Earth & 12.63 \\
\hline
\end{tabular}

The chemical composition of MSW collected after sorting is presented in Table 2.

Table 2. Chemical Composition of MSW.

\begin{tabular}{|c|c|c|c|}
\hline Sr. No. & Parameters & Values Winter & Summer \\
\hline 1. & Moisture Content ( \%) & 50 & 45 \\
\hline 2. & $\mathrm{pH}$ & 6.80 & 7.02 \\
\hline 3. & Carbon ( \%) & 35.16 & 23 \\
\hline 4. & Nitrogen ( \%) & 0.86 & 1.08 \\
\hline 5. & Potassium ( \%) & 0.85 & 0.94 \\
\hline 6. & Phosphorus ( \%) & 15 & 18 \\
\hline 7. & C / N ratio & 40.88 & 21.17 \\
\hline 8. & Cellulose ( \%) & 80 & 15 \\
\hline 9. & Hemicellulose & 43.50 & 13.87 \\
\hline 10. & Lignin & 32.87 & 29.99 \\
\hline 11. & High Calorific Value (kcal / kg) & 2600 & 2100 \\
\hline
\end{tabular}

All values except $\mathrm{pH}$ and moisture content are on dry weight basis.

Several impingers were collected for 3 weeks and $\mathrm{CO}_{2}$ emission was estimated using ACE 8000 GAS ANALYSER (IR based) generally used in stack gas monitoring. The results are presented in Table 3. 
Table 3. $\mathrm{CO}_{2}$ emission estimation from laboratory set-up.

\begin{tabular}{cccc}
\hline Sample No. & $\mathrm{O}_{2}$ & $\mathrm{CO}$ & $\mathrm{CO}_{2}$ \\
\hline $\begin{array}{c}\text { Atmospheric } \\
\text { Condition }\end{array}$ & $20.4 \%$ & $\mathrm{NIL}$ & $0.3 \%$ \\
\hline 1 & $20.2 \%$ & NIL & $0.7 \%$ \\
\hline 2 & $20.2 \%$ & NIL & $0.7 \%$ \\
\hline 3 & $20.1 \%$ & NIL & $0.55 \%$ \\
\hline 4 & $20.0 \%$ & NIL & $0.5 \%$ \\
\hline 5 & $20.0 \%$ & NIL & $0.6 \%$ \\
\hline 6 & $19.9 \%$ & NIL & $0.8 \%$ \\
\hline
\end{tabular}

From Table 3, it is concluded that $1 \mathrm{~kg}$ of waste emits $0.3 \%$ of $\mathrm{CO}_{2}$. Thus, $100 \mathrm{~kg}$ of waste placed in windrows will emit $30 \%$ of $\mathrm{CO}_{2}$.

Theoretically calculated value of $\mathrm{CO}_{2}$ emission is $18.9416 \mathrm{~kg}$ per $100 \mathrm{~kg}$ of biodegradable waste i.e., $18.9461 \mathrm{~kg}$ of $\mathrm{CO}_{2}$ emission per ton of biodegradable waste.

\section{CONCLUSIONS}

Based on the waste composition and the alternatives for waste management, it can be seen that the most cost-effective solution to reduce GHG emissions from MSW is to compost it aerobically. The infrastructure needed is rather simple and the time needed for implementation is rather short compared with other technologies. Political or serious public opposition is not anticipated, nevertheless, a NIMBY (Not in My Back Yard) syndrome might prolong the time needed to start constructing such plants.

Nevertheless, in respect to other sectors contributing to GHG emissions (i.e., energy production, transportation sector, etc.) expeditious reduction in the waste sector is needed. The costs of reducing each ton of $\mathrm{CO}_{2}$ eq. calculated for a $20 \mathrm{yr}$. range are lower by a factor of about 2.6. Steps taken to minimize GHG emission of the waste sector should play a significant role in the short and medium term and thus should not be aimed at a long-term steady-state solution.

The composting option that does not require high investments and produces a product that can be readily utilized by the agricultural sector may be a proper interim solution to mitigate GHG emission by most countries, particularly developing ones.

The dominant effect of MSW on GHG emissions and global climate change calls for intensive scientific, economic and political efforts in order to minimize the emissions from this sector. The means to achieve the goal of reducing GHG emissions should be cost-effective (i.e., adopting the least cost option). The benefits from a proper management of the waste will not only contribute significantly to the reduction of GHG emissions, but it will play a significant role in other environmental topics, such as proper management of the waste as well as resource conservation. 
Composting is an effective treatment method addressing:

- It is a simple low-cost technology, although processing methods can be deployed to encourage the composting process;

- Almost one-third of the waste tonnage is lost to $\mathrm{CO}_{2}$ and water through the composting process;

- The resulting compost material can be put to beneficial use on land;

- The $\mathrm{CO}_{2}$ released from composting can be sequestered and transformed into various forms of energy thus preventing the conventional energy sources from being depleted.

\section{REFERENCES}

[1] Assessment of status of municipal solid waste management in metro, class I cities and class II towns of India, NEERI Report, 2005.

[2] World bank document on carbon credit from composting of municipal solid waste, India, 2004. 